NBER WORKING PAPER SERIES

\title{
CHOICE OVERLOAD? PARTICIPATION AND ASSET ALLOCATION IN FRENCH EMPLOYER-SPONSORED SAVING PLANS
}

\author{
Marie Briere \\ James M. Poterba \\ Ariane Szafarz \\ Working Paper 29601 \\ http://www.nber.org/papers/w29601 \\ NATIONAL BUREAU OF ECONOMIC RESEARCH \\ 1050 Massachusetts Avenue \\ Cambridge, MA 02138 \\ December 2021
}

The authors thank Alberto Abadie, John Beshears, Marcel Gehrung, David Laibson, Vincent Pons, and Ilan Tojerow for useful comments and discussions and are grateful to Benoit Chenet, Xavier Collot, Laure Delahousse, Corinne Laboureix, Olivier Melennec, Jean-Pierre Poulet for insightful explanations on the institutional setting, and to Jerome Baudrand, Arnaud Delavoet for the data gathering process. Poterba is a trustee of the College Retirement Equity Fund and TIAACREF Mutual Funds. The data used to carry out this study come from the processing of record keeping and account keeping of AMUNDI ESR employee and pension savings accounts. These data have been analyzed anonymously for scientific, statistical, or historical research purposes. The views expressed herein are those of the authors and do not necessarily reflect the views of the National Bureau of Economic Research.

At least one co-author has disclosed additional relationships of potential relevance for this research. Further information is available online at http://www.nber.org/papers/w29601.ack

NBER working papers are circulated for discussion and comment purposes. They have not been peer-reviewed or been subject to the review by the NBER Board of Directors that accompanies official NBER publications.

(C) 2021 by Marie Briere, James M. Poterba, and Ariane Szafarz. All rights reserved. Short sections of text, not to exceed two paragraphs, may be quoted without explicit permission provided that full credit, including $\odot$ notice, is given to the source. 
Choice Overload? Participation and Asset Allocation in French Employer-Sponsored Saving Plans

Marie Briere, James M. Poterba, and Ariane Szafarz

NBER Working Paper No. 29601

December 2021

JEL No. G41,G5,G51,H24,J14

\section{ABSTRACT}

This paper employs administrative data from one of the largest plan providers in France to investigate the role of plan and default characteristics in affecting whether employees participate in the plan and whether they accept its default investment option. The dataset includes information on the saving choices of 680,392 active employees at 1,610 firms. French employers have wide discretion in structuring employee saving plans. All plans must offer medium-term investments, which cannot be accessed for five years. Employers may also offer long-term investments that cannot be accessed until retirement. When plans include a long-term option, participation is lower than when the plan offers only more liquid medium term investments. The presence of a long-term saving option also reduces the take-up of the plan's default investment allocation, which must include a long-term component. One interpretation of the findings, consistent with the theory of choice overload, is that some employees are unwilling to forego the liquidity of the medium-term option but find it costly to make an active election when they opt out of the default, and therefore choose not to participate in the plan at all.

Marie Briere

Amundi

91 bd Pasteur, 75015 Paris, France

and Paris Dauphine University

and also Université Libre de Bruxelles

marie.briere@amundi.com

James M. Poterba

Department of Economics, E52-444

MIT

77 Massachusetts Avenue

Cambridge, MA 02139

and NBER

poterba@nber.org
Ariane Szafarz

Centre Emile Bernheim

Solvay Brussels School of Economics

and Management

Université Libre de Bruxelles

and New York University

aszafarz@ulb.ac.be 
Finding ways to induce employees to participate in employer-sponsored saving plans in is a challenge facing employers and policy-makers in many nations. A large literature, surveyed by Madrian (2012), examines the determinants of employee participation and contribution levels in these plans. Employer matching of worker contributions is widely viewed as one of the most powerful incentives for worker participation in these plans. Yet evidence from the U.S., for example Choi, Laibson, and Madrian (2011), suggests that even when offered a match, some workers choose not to contribute. A number of studies have shown that defaults play an important role in affecting participants' choices in retirement plans, and that automatic enrollment is a powerful tool for increasing participation.

This paper examines the determinants of saving contributions in France, a nation in which voluntary retirement saving is less important than in the U.S., but in which savings plans exhibit a much richer structure. French firms have more discretion in setting match rates than their U.S. counterparts, in part because the stakes are lower and most retirement income is provided through a public pay-as-you-go pension system. Plans can offer saving options with different degrees of preretirement access, and firms can match contributions to different investment options at different rates. Plans may also offer piecewise linear match rate schedules with declining match rates as the amount contributed rises. At many firms, workers are confronted with complex saving options. . This not only raises the question of how potential participants evaluate different choices, but also invites the possibility that simple heuristics are used to make saving decisions.

All employer-sponsored saving plans in France feature automatic enrollment, so the two key decisions facing potential participants are whether to opt-out of the plan, and whether to select an investment allocation other than the default option. The multi-dimensional heterogeneity of firmsponsored saving plans presents an opportunity to study the plan attributes that have the largest impact on participation decisions and on decisions to opt out of the default offering conditional on participation. We refer to the plan attributes that have a stable and substantial impact on participant choices as "essential characteristics." When confronting multiple complex decisions, such as whether to participate and how to invest conditional on participation, some individuals may focus their limited attention on essential attributes.

This paper analyzes administrative data from one of the largest retirement plan provider in France, to study the relationship between retirement plan and worker characteristics and participation in employer-provided saving plans. It begins with a description of the institutional setting for 
employer-sponsored savings plans in France, and then examines the choices of close to 650,000 workers at over 1,500 firms. A notch in the tax treatment of saving plan contributions generates larger incentives for generous employer matching, at rates of up to 300\%, at firms with less than 50 employees than at larger firms. We exclude these firms from our analysis and focus on firms with at least 50 workers.

There are important differences across plans in the liquidity of the various investment options. All French firms are required to offer “medium term” (MT) investment options. Participants can withdraw MT assets after five years. In addition, firms may choose to offer long-term (LT) investment options that restrict access to the invested assets until retirement. Two regulations constrain the default options that firms may offer in their plans. The default may not include company stock, and if the plan offers both a long-term saving option and profit-sharing compensation, it must include LT savings. Since all employer-sponsored plans feature automatic enrollment, the active decisions facing an employee are whether to opt out of the plan, and, conditional on choosing to participate, whether to accept the default investment allocation or to select an alternative. French employers may choose to match contributions to some investment options in their plan, but not others. This is a contrast to the setting in the U.S. and some other nations, where the employer match is related to the level of contributions but not to the allocation of those contributions across investment options.

We find that the rate of employee participation in the saving plan varies significantly across plans with different characteristics. The presence of an LT investment option, of company stock as an investment option, and of a firm matching contribution are correlated with the participation rate. Two plan attributes, presence of an LT investment option and availability of company stock investment, also have a significant impact on the likelihood that participants will choose the default. When the plan offers a LT investment option, participation is lower than when it does not. Take-up of the default option, which must include a LT investment component in such plans, is also lower.

Our findings suggest that at least some workers prefer more liquid account options and that they are prepared to forego matching benefits that may be associated with LT accounts to invest in more liquid alternatives. In Brière, Poterba, and Szafarz (forthcoming), we refer to this as precautionary demand for liquidity. Our findings suggest that the nature of the default offering has an important effect on the probability that participants will select it. To explain why default options that some workers find unattractive are associated not only with lower take-up of the default, but also with lower plan participation, we invoke the theory of choice overload, a concept that is based in psychological 
studies such as Iyengar and Lepper (2000) and that has been constructively applied in marketing, as summarized by Scheibehenne, Greifeneder, and Todd (2021). Existing research on choice overload in the retirement saving setting has reached mixed conclusions. Iyengar, Huberman, and Jiang (2004) apply choice overload and find some support for its predictions. Recent experimental work by Cardella, Kalenkoski, and Parent (2021), in contrast, does not support the value of this concept.

This paper is divided into five sections. The first describes the institutional structure of voluntary retirement saving plans in France. Section two describes the administrative data on employer-provided plans that we analyze. It presents summary statistics at the firm level, corresponding to plans, and at the employee level. The overall participation rate in our sample is very high - roughly $90 \%$-- and about $25 \%$ of eligible employees select the default plan offering. The third section motivates our focus on a small set of characteristics based on the literature on how choice architecture affects participant choices in retirement plans. Section four examines how plan characteristics affect the probability of participant take-up of both the plan and the default. A brief conclusion summarizes our results and suggests directions for future work.

\section{Defined Contribution Plans in France}

The total compensation paid by French corporations to their workers has three components: a fixed wage, an individual bonus, and variable compensation. The fixed wage is constrained by numerous legal restrictions, including an overall minimum, and sector-based conventions with worker representatives (unions). It is a contractual unconditional amount, typically negotiated with the worker when hired. The individual bonus (if any) is fixed by the firm at the end of the year, conditional on the worker's individual productivity. It is added to the fixed wage. The bonus is designed to create performance incentivizes. The sum of the fixed wage and the bonus is taxed at a marginal rate for labor income that reaches $41 \%$ above the $€ 75,000$ threshold, and $45 \%$ above $€ 157,000$.

Variable remuneration is determined in a way that incentivizes workers as group. It relates to the profits of the company and not to individual productivity. French companies with over 50 workers are obliged to offer a variable compensation scheme, but they have substantial discretion with respect to the scheme's design. There are also tax incentives to offer such schemes. During the year, workers are informed about the amount of variable compensation they are entitled to. They may choose to receive this variable compensation during the year, and to have it taxed in the same way as their wage and bonus, or they may contribute their variable compensation to the firm's saving plan, in which case it will be taxed at an $8 \%$ rate. 
Variable remuneration has two parts: a compulsory profit-sharing component called "participation" and an optional one called "intéressement". The profit-sharing part depends on the firm's performance and must be allocated either uniformly across all the employees, or in proportion to their wage/seniority. Workers who have been with the firm for less than three months may be excluded from the profit-sharing program. The "intéressement part is less constrained but must be granted with a publicly known formula that is related to the firm's income or to other performance metrics, such as fulfilling of operational objectives or reducing the firm's carbon footprint. Firms that experience losses are not required to pay variable remuneration. All of the firms in our sample pay at least one type of variable remuneration.

Table 1 describes the tax treatment of the various options available to the worker. Workers may also divide their variable compensation, saving some and taking some as immediate income. Worker preferences and circumstances, as well as saving plan design, are both likely to affect decisions. The decision of the workers depends not only on their own preferences and circumstances, including their impatience and their need for liquidity, but also on the attractiveness of the plan designed by their employer.

\section{Table 1: Tax Treatment of Variable Compensation and Matching Contributions}

\begin{tabular}{|c|c|c|c|c|}
\hline & How? & $\begin{array}{l}\text { Tax treatment for firms } \\
(2017)\end{array}$ & $\begin{array}{l}\text { Tax treatment for } \\
\text { employees (2017) }\end{array}$ & Ceilings \\
\hline $\begin{array}{l}\text { Variable } \\
\text { compensation }\end{array}$ & $\begin{array}{l}\text { - Compulsory part if > } 50 \\
\text { employees + optional } \\
\text { - Must depend on firm’s } \\
\text { yearly performance } \\
\text { - Flexible design: either } \\
\text { uniform or proportional to } \\
\text { wage and/or seniority in the } \\
\text { firm }\end{array}$ & $\begin{array}{l}\text { - Tax deductible } \\
\text { - Flat social tax: 20\% } \\
\text { - Exception1: 16\% if } \\
\text { PERCO (LT savings) } \\
\text { - Exception 2: 8\% if new } \\
\text { plan (less than } 6 \text { years) and } \\
<50 \text { employees }\end{array}$ & $\begin{array}{l}\text { - Flat social tax: } 8 \% \\
\text { - In addition: taxed as } \\
\text { wages if not invested in } \\
\text { MT/LT savings AND for } \\
\text { contributions> } € 19,866 \\
\text { - When cashed out as } \\
\text { capital: } 15.5 \% \text { on returns } \\
\text { - When cashed out as an }\end{array}$ & $\begin{array}{l}\text { - Firm specific } \\
\text { ceiling that depends } \\
\text { on total wage \& } \\
\text { benefits } \\
\text { - Individual ceiling } \\
\text { - Global ceiling: } \\
\text { same for all firms }\end{array}$ \\
\hline $\begin{array}{l}\text { Matching } \\
\text { contribution }\end{array}$ & $\begin{array}{l}\text { - Optional } \\
\text { - For MT only or MT+LT } \\
\text { - Fixed design: uniform }\end{array}$ & $\begin{array}{l}\text { - Tax deductible } \\
\text { - Flat social tax: 20\% } \\
\text { - Exception1: 16\% if } \\
\text { PERCO (LT savings) }\end{array}$ & $\begin{array}{l}\text { annuity: taxed as wage } \\
\text { after an age-related } \\
\text { deduction (between 30\% } \\
\text { and 70\%) }\end{array}$ & $\begin{array}{l}\text { Global ceilings on: } \\
\text { - Match rate: } 300 \% \\
\text { - MT savings (with or } \\
\text { without company } \\
\text { stocks) } \\
\text { - LT savings }\end{array}$ \\
\hline
\end{tabular}

There are substantial participant tax benefits associated with retirement saving plans. These benefits are not affected by whether the participant chooses to elect the default investment option. For a worker who receives variable remuneration, which can be invested in the firm-sponsored plan, but 
chooses not to participate in a saving plan, the resulting income payout is taxable at rates of up to $45 \%$. In contrast, if the funds are invested in a saving plan, they may be eligible for a matching contribution and they will not be taxed until they are withdrawn from the plan. When withdrawn, the payouts are taxed at a rate of $8 \%$. Participating in the employer play can thus reduce the tax burden by more than 30 percentage points.

\subsection{Characteristics of French DC Plans}

French defined-contribution (DC) plans were created in 1967 by then-president Charles de Gaulle as part of a program designed to require corporations share their profits with their employees. Firms with more than 50 employees were required to offer their employees DC plans. DC plans were part of a policy program that involved tax incentives for variable compensation and offerings of company stock at below-market prices. DC plans were not primarily motivated by a desire to improve retirement security. The system started with medium-term (MT) saving options, which required that funds be invested for five years before becoming available for withdrawal without any penalty and without any restrictions on the purpose of the withdrawal. Today, firms may also offer their employees long-term (LT) investment options that restrict access to the invested assets until retirement.

The French public pension system, the counterpart to Social Security in the U.S., is a mandatory program that offers up to $50 \%$ of a retiree's final earnings ( $1^{\text {st }}$ pillar) as well as a mandatory and somewhat redistributive occupational pension provision that increases the income of retirees from $50 \%$ to $70-80 \%$ ( $2^{\text {nd }}$ pillar). The third pillar of the retirement saving system, private pensions, consist of employee savings’ plans, life insurance products, “plan d'épargne retraite populaire” (PERP), and a variety of other plans. DC plans are designed to encourage employees' medium-to-long term savings with employer sponsorship.

The legal environment governing DC plans is complicated and involves two types of plans: PEE (for “plan d'épargne d'entreprise”) and PERCO (for “plan d’épargne retraite collective”). ${ }^{1}$ Unless an employee opts out, his or her annual variable remuneration is automatically credited to a PEE or PERCO account in the custodian chosen by the employer. PEE is for MT savings. Withdrawals are forbidden during a five-year period, although there are exceptions for events such as marriage, birth of a child, purchase of a home, and some other life events. PERCO works similarly but targets LT

\footnotetext{
${ }^{1}$ Two additional structures, PEG ("plan d'épargne groupe”) and PEI (“plan d'épargne interentreprises”) are used for very large groups. They present the same characteristics as PEE and were merged with it.
} 
retirement savings. Withdrawals are blocked until retirement, although exceptions are also made for particular life events. Investment in company stock is allowed in PEE but not in PERCO accounts. In many cases, the company stock may be purchased at a discount, not exceeding 20\%. ${ }^{2}$ Beyond investing their variable remuneration in a PEE or PERCO, and thereby deferring taxes on this income, employees can also make after-tax voluntary contributions of up to $25 \%$ of their earnings to their employer-sponsored plan. All contributions to the plan may be eligible for employer matching contributions; $42 \%$ of firms in our sample offer a match.

In designing a DC saving plan, the employer makes three key choices that affect the plan default. First, the firm selects a collection of investment funds among which employees can choose to allocate their contributions, along with a default investment fund for MT, and possibly LT, savings. The default MT fund must be a relatively low-risk fund (money market, bond or balanced fund). The default LT fund must be a balanced fund. Second, the employer chooses whether to offer a PERCO (LT savings) in addition to the compulsory PEE (MT savings). PERCO components are optional. If the menu includes LT savings, then it must also come with a default LT option, a balanced life-cycle fund. In this case, the share of LT savings in the default option is fixed by law depending on the type of variable remuneration paid. For profit-sharing remuneration, the default option allocates $50 \%$ of the employee's contribution to the MT default fund and 50\% to the LT default fund. For "intéressement" remuneration, the default allocation is only to the MT. There is substantial variation across firms in the MT and LT investment choices available to workers. Some firms offer only low-risk and well diversified funds on their investment menus, while others offer riskier options. In our sample, the number of investment funds offered ranges from 1 to 50 .

Third, when creating a plan, the employer chooses whether and how to match the worker's contributions to the plan. Matching requires choosing a list of match rates and match ceilings associated with each investment option. Match rates can vary across options and the match function must be structured as a piecewise linear non-increasing step function with no more than six steps. The match rates can be as high as $300 \%$. Each matching structure can include as many as 20 parameters. Since firms can choose different matching formulas for different investment options, a firm interested in encouraging employees to hold company stock might offer a higher match rate for MT company stock than on other investment options. Although firms could design very complex rules, in practice

\footnotetext{
${ }^{2}$ https://www.impots.gouv.fr/portail/www2/precis/millesime/2017-2/precis-2017-chapter-2.5.1.html?version=20170701.
} 
most firms chose simple formulae, such as a flat match for all workers that is identical across funds. A firm may cap its matching contribution to each fund.

The default option may or may not be matched. ${ }^{3}$ Offering matching contributions has pluses and minuses for the firm. The pluses include tax-deductibility of these contributions and the possibility that a listed company may increase the share of its outstanding stock held by "friendly" employee owners and thereby reduce takeover threats. ${ }^{4}$ In small firms, high match rates can allow ownermanagers to provide additional compensation to the employees with the financial capacity to take advantage of the matching provisions, while also allowing these employees to take advantage of tax deferral. There is an annual limit, per employee, on the amount of retirement plan contributions that can be exempt from taxation. The limit varies by investment choice. In 2017, the overall ceiling was $€ 9,414$ for matching plans that exclude company stocks, and €11,924 for those that include them. Matching contributions must be offered uniformly to all employees or in a graduated fashion that is proportional to employee seniority. The match rate may not depend on wages, which makes it difficult to restrict the advantage of matching to a limited group of beneficiaries. Some managers may, however, provide relatively limited information about matching provisions to their employees, and they may design complex plan structures that make it difficult for employees to evaluate their options. Employers have a responsibility under Article L.3332-7 of the French Labor Code to inform employees of the existence of the company savings plan and of its structure. ${ }^{5}$

\subsection{Regulatory Constraints on Saving Plan Structure}

French law requires any firm that shows a profit for the year on its annual financial statements to provide variable compensation and DC plans to their employees. An employee has three options for the disposition of his or her variable remuneration: 1) invest all of it in the default plan; 2) opt out the default option and invest all or part of it in any combination of funds offered by the firm; and 3) opt out of the savings plan and pay regular taxes on the variable remuneration. In the third case, the total tax burden on the variable remuneration is likely to be higher than in either of the first two. The first

\footnotetext{
3 The employers may define specific match ceilings for LT and MT savings, so that the amounts matched in the fifty-fifty arrangements might end up being different.

${ }^{4}$ Since 1994, when worker shareholdings exceed a 5\% threshold (reduced to 3\% in 2002), the company must periodically propose to the extraordinary general meeting to designate a board member who will represent worker shareholdings. ${ }^{5}$ A description of the employer's responsibility may be found at https:/www.netpme.fr/actualite/epargne-salarialeobligation-informationemployeur/\#: :text=3332\%2D7\%20du\%20code\%20du,obligation\%20d'information\%20des\%20salari\%C3\%A9s.\&text=Es timant\%20que\%20les\%20versements\%20qu,lui\%20avait\%20refus\%C3\%A9\%20l'abondement.
} 
possibility is the passive or "no opt-out" option. Employees have about one month to let their employer know if they are choosing option 2 or 3 . If they $\mathrm{d}^{*} \mathrm{o}$ not provide timely notification to their employer, their variable remuneration is automatically invested in the default plan.

France places several restrictions on the options that can be offered in saving plans, these are summarized, and contrasted with regulations in the U.S., in Appendix A. ${ }^{6}$ All French plans must offer MT investments; they may also include LT investments that cannot be accessed until retirement. They may offer company stock, but only as an MT option. Employees are auto-enrolled in a default option that varies across plans but has to comply with two regulations: for plans with an LT investment component, the default must include LT funds, and the default plan cannot include company stock.

There are overall limits on the match amounts for both MT and LT plans. In 2017, those limits were $€ 5,648$ for company stock, €3,138 for other MT funds, and €6,276 for LT funds. Thus, employees in a firm offering all three categories of matched options could receive matching contributions of up to $€ 11,924$. None of the employees in our sample were constrained by this limit, although some were constrained by component limits, such as the constraint on matching contributions to employer stock.

\section{Data on DC Plans and Their Participants}

We analyze administrative data for 2017 collected by one of the largest providers of DC plans in France. The data set includes information on the saving choices of 645,966 active employees who were no more than 67 years old, lived in France, worked at one of 1,583 firms with at least 50 employees, and received variable remuneration from their employer.

Table 2, Panel A, reports the characteristics of the sample firms. The average firm's workforce is $40 \%$ female, and the cross-firm average of the median worker age is 45.6 years. The median variable remuneration for a worker, averaged across firms, is $€ 1,761$. About one third of firms offer LT savings in addition to the mandatory MT funds, and roughly one quarter offer company stock. Most companystock funds are fully invested in company stock; some offer a capital guarantee or leverage. In addition, $42 \%$ of firms match some, and possibly all, funds in the plan. On average, firms offer 7.2 funds on their MT menu, and 2.9 of the four core asset classes (diversified stock funds, bond funds,

\footnotetext{
${ }^{6}$ The Employee Benefits Security Administration of the U.S. Department of Labor issued regulations in 2007 specifying a set of Qualified Default Investment Alternatives (QDIAs). Some asset classes, notably company stock, are generally excluded from plan defaults, but employers have substantial discretion in selecting default options. Employers who select investment options that meet the QDIA criteria have a "safe harbor" protection against future lawsuits by participants. For at https://www.federalregister.gov/documents/2007/10/24/07-5147/default-investment-alternatives-under-participantdirected-individual-account-plans
} 
balanced funds, and money market funds). The most common fund categories in the MT menu are balanced funds and diversified stock funds.

Table 2: Descriptive Statistics on Firms and Plan Participants

\begin{tabular}{|c|c|c|c|c|}
\hline & \multicolumn{2}{|c|}{$\begin{array}{c}\text { Panel A } \\
\text { Across firms }(\mathrm{N}=1,583) \\
\end{array}$} & \multicolumn{2}{|c|}{$\begin{array}{c}\text { Panel B } \\
\text { Across individuals }(\mathrm{N}=645,966)\end{array}$} \\
\hline Variable & Mean (S.D.) & Median & Mean (S.D.) & Median \\
\hline Female & $0.40(0.22)$ & 0.36 & $0.34(0.47)$ & 0 \\
\hline Age (median for firms) & $45.60(5.96)$ & 46.0 & $44.6(11.0)$ & 45.0 \\
\hline $\begin{array}{l}\text { Variable Remuneration (VR) } \\
(€) \text { (median for firms) }\end{array}$ & $1,761(2,852)$ & 859 & $2,115(3,073)$ & 1,004 \\
\hline Profit sharing $(\mathrm{Y} / \mathrm{N})$ & $0.70(0.46)$ & 1.0 & $0.58(0.49)$ & 1.0 \\
\hline VR in Quartile $1(€)$ & $857(1,193)$ & 461 & $801(1,216)$ & 294 \\
\hline VR in Quartile 2 & $1,834(2,669)$ & 886 & $1.753(2.204)$ & 890 \\
\hline VR in Quartile 3 & $2,269(2,376)$ & 1,535 & $2,341(2.695)$ & 1,457 \\
\hline VR in Quartile 4 & $2,741(3,851)$ & 1,510 & $3,364(4.342)$ & 2,041 \\
\hline $\begin{array}{l}\text { Plan balance (€000s)(median } \\
\text { for firms) }\end{array}$ & $9.271(18.497)$ & 4.133 & $24.692(65.824)$ & 5.954 \\
\hline $\begin{array}{l}\text { Ln (plan balance) (median for } \\
\text { firms) }\end{array}$ & $8.33(1.47)$ & 8.47 & $8.4(2.1)$ & 8.7 \\
\hline Plan w/ LT savings & $0.34(0.48)$ & 0 & $0.51(0.50)$ & 1.0 \\
\hline Plan w/ employer stock & $0.23(0.42)$ & 0 & $0.65(0.48)$ & 1.0 \\
\hline Plan w/ match & $0.42(0.49)$ & 0 & $0.68(0.47)$ & 1.0 \\
\hline \# funds on MT menu & $7.20(5.00)$ & 6.0 & $7.24(4.34)$ & 6.0 \\
\hline \# asset classes in plan & $2.91(0.96)$ & 3.0 & $3.08(0.86)$ & 3.0 \\
\hline Take-up of plan & $0.88(0.19)$ & 0.98 & $0.87(0.34)$ & 1.0 \\
\hline Take-up of default option & $0.27(0.31)$ & 0.13 & $0.25(0.43)$ & 0.0 \\
\hline
\end{tabular}

Source: Authors' tabulations. The variable remuneration (VR) quartiles in Panel A are obtained using within-quartile medians.

Our analysis focuses on participants' decisions as a function of plan attributes, so we also summarize the characteristics of the employees in our sample. Table 2, Panel B, provides descriptive statistics on the employees of the firms: $34 \%$ are women and the average age is 44.6. The mean employee plan balance is just over $€ 24,000$, with large positive skew: the median balance is less than $€ 6,000$. Variable remuneration averages $€ 2,115$ and displays a skewed distribution since the median is only half this value. There is substantial variation in the median amount of variable remuneration across firms, and in variable remuneration across workers within firms. The equal-weighted cross-firm average of the median variable remuneration is $€ 1,761$, with a standard deviation is $€ 2,852 .{ }^{7}$ With regard to plan structure, 51\% of employees are offered plans with LT as well as MT components. 65\%

\footnotetext{
${ }^{7}$ One way to address the heterogeneity across firms in the level of variable remuneration, which we pursue, is to focus on the percentile of employees within their firm.
} 
of the employees work for firms at which it is possible to invest in employer stock. $68 \%$ of the employees are offered plans with some matching opportunities. The average number of funds on the MT menu is seven ${ }^{8}$, and the average worker is offered investments in three asset classes.

Figure 1 shows the size distribution of firms, measured by the natural log of the number of employees (recall that $\ln (50)=3.91$ and $\ln (1,000)=6.9)$. About $18 \%$ of the firms have fewer than 100 employees, and 83\% have fewer than 1,000 employees. Less than two percent of the firms (1.7\%) have more than 10,000 employees, but the workers at these firms account for $47 \%$ of all employees in the sample. For this reason, we present some results that compare averaging across workers with averaging across firms.

\section{Figure 1: Histogram of Firm Size (Number of Employees)}

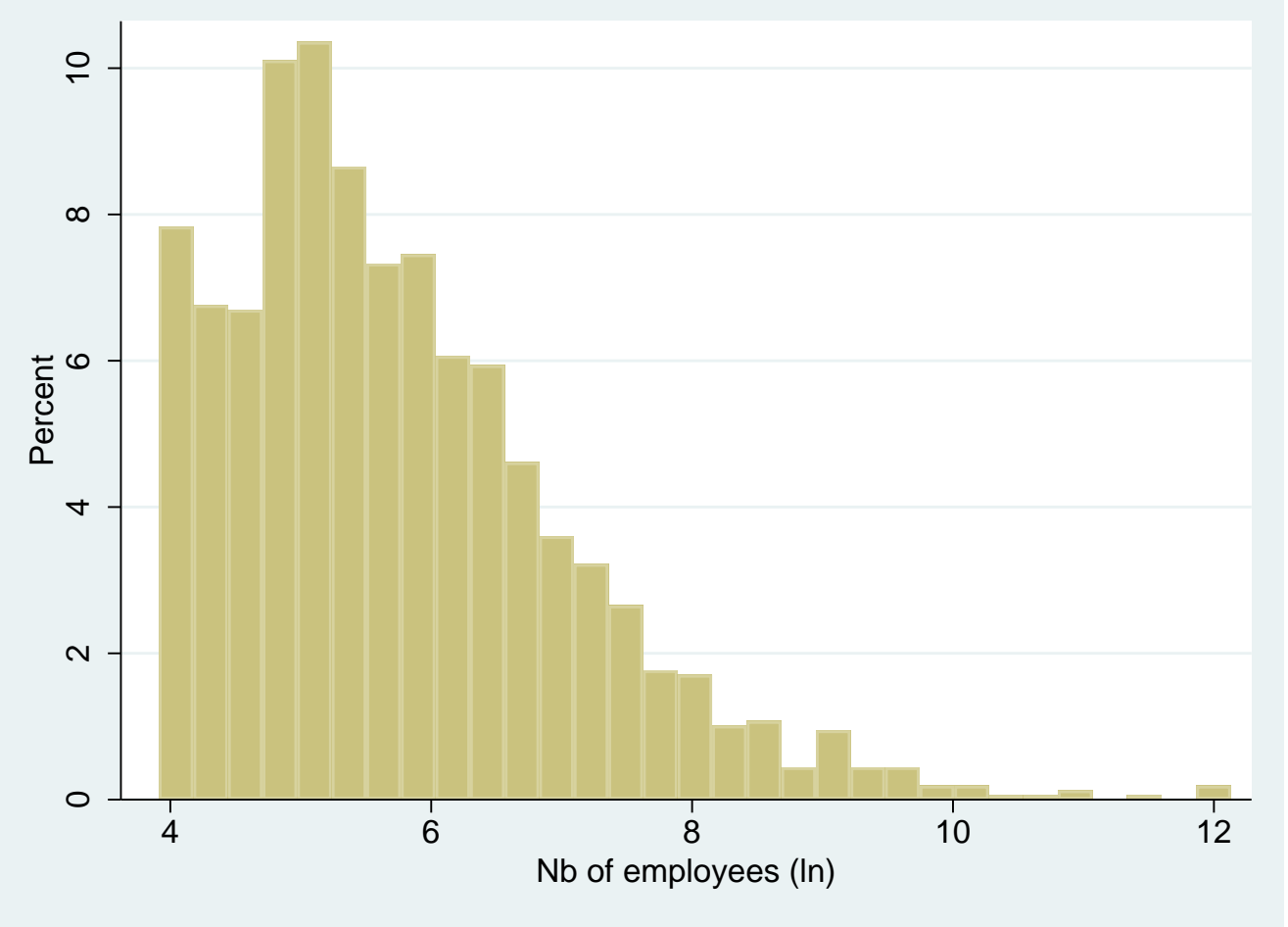

\section{Choice Architecture and Retirement Plan Attributes}

Many studies have examined the impact of retirement plan characteristics, especially the presence of auto-enrollment defaults for contribution levels or investment allocations, on the behavior of plan participants. In the U.S., automatic enrollment grew in popularity after regulatory action in 2007 provided employers with a "safe harbor" from litigation if they adopted auto-enrollment.

\footnotetext{
${ }^{8}$ Huberman and Jian (2006) observe that the number of funds used by investors does not depend on the number of funds in the plan. Brown et al. (2007) find however that the number of options in each asset class has an impact on portfolio allocation across classes.
} 
Beshears, et al. (2010) point out that many firms embraced automatic enrolment as a tool for increasing plan participation and ensuring that the retirement plan passes the Internal Revenue Service nondiscrimination test, which caps the share of contributions to the plan that can be made by highly compensated employees. There is robust evidence that defaults matter ${ }^{9}$, which is consistent with some participants following simple heuristics to reduce the cost of choosing contribution levels and investment options. Madrian \& Shea (2001) attribute the widespread take-up of default options at least in part to inertia, which may be an outcome of the "choice overload" discussed in Schwartz (2004).

\subsection{Choice Architecture}

Because employer-sponsored savings plans in France are more complex than their U.S. counterparts, behavioral considerations such as limited attention and costly decision-making may be even more important for understanding participants’ choices. The French system relies on automatic enrollment and regulates the nature of the default option in DC plans, while allowing employers wide discretion regarding the menu of plan investment and default options. In the widely studied U.S. retirement market, most defined contribution plans offer similar default options, often a target-date fund or a low-cost index equity fund. The lack of variation in the defaults makes it difficult to separate the impact of default provisions from the presence of the default itself. The French context, in contrast, offers rich variation in default options, which enables us to explore how characteristics of the default, such as whether it includes a matching contribution and whether it involves a liquid or illiquid account, influence plan participation.

Table 3 summarizes the choices facing French workers. At one extreme, they may opt-in to the plan and accept the default investment allocation; this requires relatively little decision effort. At the other extreme, opting not to participate in the plan is also an "easy" choice. Intermediate cases, which are the most common choices in our sample, involve choosing to participate but not to accept the default. Nearly two thirds of plan participants opt out of the default and make an active choice. Beshears et al. (2019) show that characteristics of the default option affect the likelihood of making an active choice. Regulatory restrictions on the defaults offered by French employers may render them

\footnotetext{
${ }^{9}$ A number of recent studies confirm earlier findings, summarized in Beshears, et al. (2009), that defaults matter. Falk and Karamcheva (2019) study the introduction of automatic enrollment in the US Thrift Savings Plan (TSP) for federal employees and members of the military hired after July 2010. McDonald, Richardson, and Rietz (2021) study a change in the default option in one plan, from a money market fund to a target date fund, and show that it affected asset allocation and the speed with which participants shifted away from the default. Cribb and Emerson (2020) study a UK change, starting in 2012, that involved a progressive roll-out of compulsory automatic enrolment for employer-provided plans. Clark and Young (2018) find that among new hires, the participation rate is 93\% under automatic enrollment, compared with $47 \%$ when enrollment was voluntary.
} 
unattractive and encourage active choice, but this imposes a complex decision task on workers. In this situation, for some, choice overload considerations may become relevant.

Table 3: Potential Consequences of Opting-in vs. Opting-out

\begin{tabular}{|l|c|c|c|}
\hline \multirow{2}{*}{} & \multicolumn{2}{|c|}{ Participate } & $\begin{array}{c}\text { Cash Out Variable } \\
\text { Remuneration }\end{array}$ \\
\cline { 2 - 4 } & Accept Default & $\begin{array}{c}\text { Opt-Out of } \\
\text { Default }\end{array}$ & Opt-out \\
\cline { 2 - 4 } $\begin{array}{l}\text { Number of } \\
\text { workers }\end{array}$ & $\mathbf{1 5 8 , 5 6 9}$ & $\mathbf{4 0 2 , 2 5 1}$ & \multirow{2}{*}{$\mathbf{8 5 , 1 4 6}$} \\
\hline Maximize tax \\
benefits?
\end{tabular}

A worker who chooses to participate in a plan, but not to accept the default, must decide how much variable remuneration to contribute to the plan and how to allocate contributions across investment options. For workers who are burdened by choice overload, an attractive default may not just attract a substantial number of those who participate, but it may also increase the share who choose to participate. Some workers may feel comfortable selecting the default option, rather than carrying out an explicit portfolio choice analysis with regard to their contribution allocation. Since French law requires that the default fund must be low-risk or balanced, opting for the default is a safe and simple way for the participant to take advantage of the tax benefit. Caplin and Martin (2015) argue that features like these can be important in supporting choices without a detailed analytical assessment. Tse, Friesen, and Kalaycı (2016) present some evidence that when retirement plans are more complex, and the choices among investment options are therefore more daunting, participants are more likely to choose the default, even when it does not seem like a well-suited choice for them. ${ }^{10}$

\footnotetext{
${ }^{10}$ Dahlquist, Setty, and Vestman (2018) suggest that in the U.S., the default option does not coincide with the asset allocation that would be dictated by optimal portfolio selection.
} 
Prior research suggests a number of factors, including limited financial literacy, procrastination, lack of attention, and aversion to complexity, that can stand in the way of participants carrying out a full optimization analysis of potential choices.

Köszegi and Matejka (2020) consider an alternative to complete optimization: simplified choice based on limited attention to a small number of important and decision-relevant factors. We apply this theory to participant choices by focusing on "essential attributes” of plan offerings. Decisions about whether to participate in the plan, and whether to accept the default offering conditional on participation, can both be affected by essential attributes. When a plan features only a single essential attribute, workers will make choices based on whether that attribute of the plan, or of its default allocation, aligns with their preferences. For example, if a plan offers both MT and LT menus, a participant for whom a preference for liquidity is an essential attribute may decide to select investment options from only the LT menu. Investment liquidity, an essential attribute, may also determine participation in the plan.

Two regulatory requirements in France create exogenous variation in the structure of default options that we exploit in our empirical analysis. First, any firm that offers profit sharing to its workers and that offers an LT option must include LT investments in its default option. Second, firms may not offer employer stock in their default option. These restrictions imply that the inclusion of illiquid savings options in the default, and the exclusion of employer stock, are not the result of employer discretion in plan design. We study how these attributes of the default option affect the probability that participants select the default and elect to participate in the savings plan. The regulatory constraints impose certain actions on workers with particular preferences. For example, an individual who wants to participate in the saving plan, but has a strong preference for a liquid investment option, is compelled to opt out of the default. A similar issue can arise with respect to company stock: a worker who wants to invest in company stock must opt out of the default. In contrast to offering LT options and company stock, employer matching contributions, another plan attribute that employees might consider “essential,” are lightly regulated. There is a 300\% maximal match rate and there are thresholds for match amounts, but no other restrictions.

The choice problem is especially complicated when plans feature more than one essential attribute, creating potential trade-off for those who wish to make simplified choices. One such tradeoff arises when the plan offers a match and a LT investment option, with the match directed to the LT investment. Similarly, if a firm matches investments in company stock, which cannot be included in 
the default, this reduces the relative attractiveness of the default option. Our empirical analysis provides some evidence on the relationship between essential attributes and participation decisions.

The three plan features that we consider as essential attributes - the presence of an LT investment option, the availability of company stock, and employer matching contributions - have attracted substantial attention in past research on retirement saving behavior. In the framework developed by Huang and Liu (2007), all three have potentially important effects on participants' financial status, and relatively low learning costs. The availability of an LT option raises issues associated with commitment contracts and the temptation to draw down funds before retirement, which are discussed by Laibson (2015) and Houser et al. (2018). With regard to company stock, Benartzi (2001) and Agnew, Balduzi, and Sunden (2003) report that in the 1990s, employees from large US companies invested a significant share - one third or even more of retirement plan assets - in employer stock. The share has declined since then. One explanation for holding company stock, which is an anti-diversifying behavior given the correlation between the company's market value and the value of the participant's human capital, is that employees are over-confident and place excessive weight on past returns of their company's stock in projecting future returns. ${ }^{11}$

Madrian (2012) reports that matching contributions appear to increase plan participation, but with a modest quantitative effect. Even and Macpherson (2005) suggest that matching, like automatic enrollment, is sometimes used to help plan sponsors in the U.S. satisfy non-discrimination rules by raising participation. Puzzles can arise when employees do not take advantage of the match and appear to leave a significant amount of money “on the table”? Dworak-Fisher (2011) and Choi et al (2017), among others, raise this issue. Various potential explanations have been suggested. Engelhardt \& Kumar (2008) suggest liquidity constraints, Duflo \& Saez (2003) suggest imperfect information, Chetty et al. (2014) and Anderson (2018) suggest behavioral biases such as inattention and passivity, and Choi et al. (2017) suggest anchoring. Historically, some U.S. firms directed their matching contributions to company stock. Workers might have preferred matching contributions in a form that they could allocate as they saw fit, but still found the terms of such a matching arrangement attractive.

Table 4 shows the distribution of firms and employees in our sample with respect to the three essential attributes of interest. For each combination of essential attributes, it also shows the number of plan participants and the share of plan-eligible employees who select the default investment option.

\footnotetext{
${ }^{11}$ Many studies have pointed to the correlation between company stock performance and participants’ human capital returns, including Papke and Poterba (1995), Choi et al. (2002), Poterba (2003), Meulbroek (2005), Brown, Liang, and Weisbenner (2007), and Engelhardt and Kumar (2007).
} 
Overall, the participation rate is high $-87 \%$ - and $25 \%$ of eligible employees choose the default. We focus on the share of eligible workers throughout our analysis because the attractiveness of the default option may affect participation decisions.

Table 4: Choice Map for Saving Plan Participants

\begin{tabular}{|c|c|c||c|c||c|c||c|c|}
\hline \multirow{2}{*}{$\begin{array}{c}\text { Employer } \\
\text { Match }\end{array}$} & $\begin{array}{c}\text { LT } \\
\text { Investment } \\
\text { Option }\end{array}$ & \multirow{2}{*}{$\begin{array}{c}\text { Company } \\
\text { stock }\end{array}$} & Firms & \multicolumn{2}{|c||}{ Workers } & \multicolumn{2}{|c|}{ Plan Participants } & \multicolumn{2}{c|}{$\begin{array}{c}\text { Takers of the } \\
\text { default option }\end{array}$} \\
\cline { 3 - 8 } & Y & N & N & $\%$ & N & $\%^{\mathrm{a}}$ \\
\hline Yes & Yes & 208 & 221,011 & 196,133 & 89 & 11,962 & 5 \\
\hline Yes & Yes & No & 201 & 75,776 & 56,228 & 74 & 12,056 & 16 \\
\hline Yes & No & Yes & $\mathbf{9 9}$ & $\mathbf{1 2 3 , 5 5 6}$ & $\mathbf{1 2 0 , 2 3 2}$ & $\mathbf{9 7}$ & $\mathbf{5 5 , 6 7 8}$ & $\mathbf{4 5}$ \\
\hline Yes & No & No & 149 & 19,999 & 17,320 & 87 & 3,846 & 19 \\
\hline No & No & No & 751 & 108,101 & 90,870 & 84 & 47,007 & 43 \\
\hline No & No & Yes & 39 & 65,127 & 56,925 & 87 & 22,373 & 34 \\
\hline No & Yes & No & 118 & 24,928 & 18,356 & 74 & 5,381 & 22 \\
\hline No & Yes & Yes & 18 & 7,468 & 4,756 & 64 & 266 & 4 \\
\hline
\end{tabular}

The percentages of workers who participate, and the percentage who take up the default option, are both calculated as shares of the total number of workers.

The entries in Table 4 show that the plan type with the highest participation rate has employer match, company stock, and no LT investment option (plan participation 97\%, take-up of default 45\%). This is the plan type that is shown in bold type. This plan type involves a coincidence of the positive effects of the three essential attributes. It is noteworthy that the plan type with no essential attributes no match, no LT investment option, and no company stock - has only a slightly lower take-up rate of the default option among eligible employees than the highest-participation configuration. This basic plan type has a plan participation rate of $84 \%$, and $43 \%$ of eligible workers choose the default. This plan type is offered by nearly half of all firms: 47\% (751 firms out of 1,583). The firms offering this option tend to be small, accounting for only $17 \%$ of workers $(108,101$ out of 645,966$)$ even though they represent nearly half of all plans. The least attractive plan type, which is offered by only 18 firms with 7,468 workers, includes an LT investment option, company stock, but no matching contributions. For this plan type, the participation rate among eligible employees is 64\%, and the take-up rate for the 
default is $4 \%$. The percentage of eligible workers opting out of the default varies more across plan types than the participation rate. Take-up of the default is below 50\% in all categories.

The plan types shown in the last two rows of Table 4 have the lowest participation rates (64\% and 74\%). They both have LT investment opportunities; neither offers an employer match. The two plan types with the lowest default take-up rates, 4 and 22\% respectively, are those in the first and last rows of the table. They both offer an LT investment option and company stock. When these two plan attributes are paired with an employer match, the take-up rate is $89 \%$, close to the average across all plans, but without the employer match, the take-up rate is $64 \%$.

\subsection{Regulatory Constraints, Plan Attributes, and Identification of Participant Behavior}

The data in Table 4 are suggestive of a relationship between the three essential plan attributes that we focus, take-up of the default option, and, to a lesser extent, plan participation. A key problem in determining whether such relationships are causal is the endogeneity stemming from the fact that the plans are designed by the employers, possibly taking into account the preferences of their workers. Plan attributes are therefore not randomly assigned to workers. Bubb, Corrigan, and Warren (2015), Bubb and Warren (2020), and Ambuehl, Bernheim, and Ockenfels (2021) note that employers’ motives may include paternalism, cost minimization, and retaining and incentivizing their workers. The role of worker preferences in determining plan attributes may be greater in France, where plan design is partly set through negotiations with unions, than in some other countries.

French regulations nevertheless create some exogenous variation in default attributes conditional on plan attributes. Even though firms determine the plan design, the default option is regulated in a way that leaves significantly less leeway to firms. Firms that wish to offer employees the chance to purchase company stock can include it on the plan menu, but not in the default option. An employee who wishes to invest in company stock through their saving plan must therefore opt out of the default. The presence of employee stock in the plan is a firm choice, but its exclusion from the default is not. Likewise, for the fraction of employers who include an LT option in addition to the compulsory MT option on their plan menu, even if they do not want to require all workers to hold LT saving since

some may be liquidity constrained or otherwise prefer not to do so, the regulations require their default asset allocation to include LT saving. Workers must therefore opt out of the default if they do not want to contribute to a relatively illiquid LT account.

In contrast to the offering of employer stock and an LT investment option, there are few constraints plan sponsors with regard to matching contributions. Employers may match any funds in 
the menu, regardless of their inclusion in the default option of the plan. Finding that the presence of an employer match raises employee participation may therefore just reflect the reaction function of employers who offer matching contributions when they are valued by their workers. Employer matches are unusual, however, because the reason a worker would participate in the plan but reject a matched saving option is not because they dislike the "free money" aspect of the match, but because he or she does not want to invest in the fund that is matched. The decision to reject the match is therefore the result of the strings attached to it.

\section{Participant Behavior and Plan Attributes}

We now consider the association between plan attributes, plan take-up, and take-up of the plan default. We compare participation rates and choice patterns in the cross-section of plans with different plan structures. We recognize that plan attributes are not randomly assigned, and underlying differences between the workers at the firms that offer these different plan options are potential confounders of our results, so we begin by comparing the employees at firms that do and do not offer various plan attributes. We rely on the regulatory constraints on the structure of employer-provided plans in France to provide some variation in attributes that may help to identify causal effects.

\subsection{How Different are the Workers at Firms with Different Plan Attributes?}

Table 5 compares the workers who are employed at firms with and without LT plan offerings, with and without employer stock as an investment option, and with and without an employer match. There are some substantial differences, but most are modest. Given the large number of employees in all the subsamples, we reject the null hypothesis of equality of the attributes of the workers at each pair of firm types.

The first two columns in Table 5 compare workers at firms without, and with, a LT plan offering. The average worker who is offered a long-term plan is about 1.5 years older, and about one percent more likely to be female. The average plan balance of workers at firms with LT offerings is 
possibility is corroborated by the greater prevalence of LT options in plans offered to workers whose firms provide profit sharing than whose firms do not (68 percent vs 47 percent).

Columns three and four compare workers at firms that offer employer stock with those that do not. The workers at firms that offer employer stock are about ten percent more likely to be male, are on average slightly less than one year older, and have variable remuneration about 20 percent lower than their counterparts at firms that do not make employer stock available. In contrast, profit sharing is more likely in plans that exclude employer stock (65 percent) than in those that offer it (54 percent).

The last two columns compare the workers at firms that offer matching contributions with those at firms that do not. The workers at firms that offer matches are, on average, about 1.7 years older, are about five percent more likely to be male, and have average plan balances about 2.5 times greater than workers at firms without a match. Variable remuneration is also about 40 percent higher, close to $€ 700$, at firms with rather than without a match. Profit sharing is more frequently observed for matchfree plans (64 percent vs 55 percent).

Table 5 also provides information on the association between various plan attributes. The entries in the fifth row, for example, show that workers who are offered employer stock are more likely (55\% vs $44 \%$ ) to be employed at a firm that offers a LT saving option. Workers who are offered a plan with a match are also much more likely to be offered an LT option (67\% vs 16\%) and to have an opportunity to invest in company stock (78\% vs $35 \%$ ). One surprising finding is that the number of MT funds available in MT-only plans is smaller than the number available in plans that offer both MT and LT options. For most employees who are offered a LT menu, the LT funds are not the same as the MT funds. This further increases the difference between MT and MT+LT plans and adds complexity to the MT+LT plans because potential participants have a larger choice set to evaluate. Workers who are and are not offered employer stock funds have access to similar numbers of MT funds. This implies that firms that offer employer stock funds tend to offer fewer balanced and equity funds than firms without employer stock funds. Whether a worker is offered a match is not correlated with the number of funds offered.

The last two rows in Table 5 report, and Figure 2 shows, summary information on participant behavior conditional on plan attributes. There are several notable differences between different types of plans. First, employees are more likely to take up MT-only plans (90 percent) than MT+LT plans (84 percent). Second, employees are more likely to take up plans that offer employee stock: 91 percent vs 80 percent. Finally, plans that offer a match are about six percentage points more likely to 
be taken up than those that do not. Employees at firms that offer a match, at firms that offer employee stock, and at firms that offer an LT investment option are less likely to accept the default investment

\section{Figure 2: Take-up of the Plan and the Default with Essential Attributes}

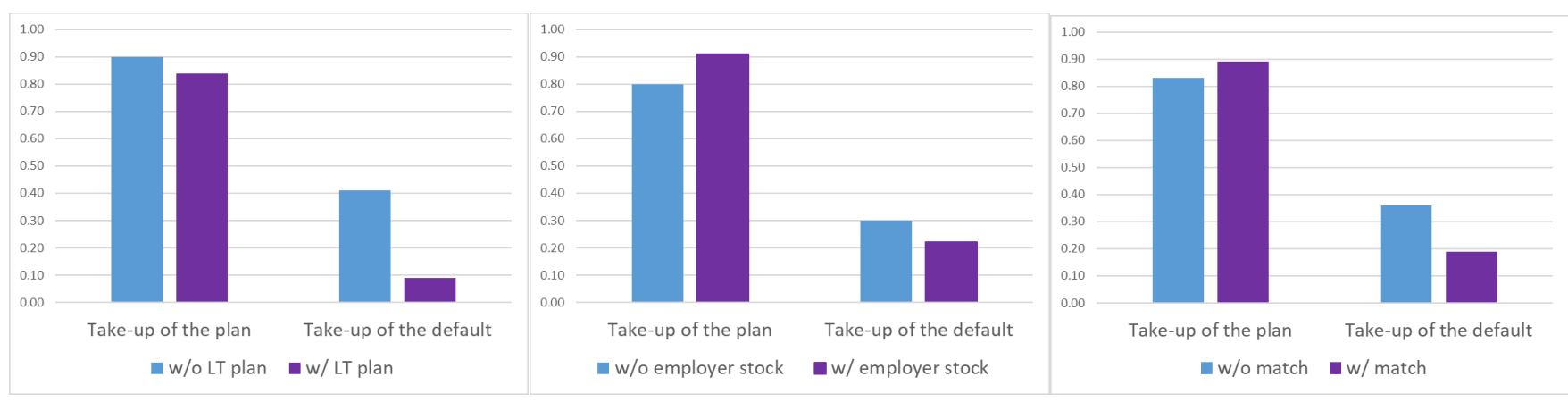

allocation. The differences are 17, 8, and 32 percentage points, respectively. These findings are consistent with the presence of a LT option, the availability of company stock investments, and the presence of a match being essential plan attributes that potential participants consider even when not making detailed assessments of plan provisions. A significant proportion of participants opt out of the default option offered by their employer when it is not attractive on one of these dimensions. Among the 108,101 workers who are offered plans that do not include a LT option or company stock, or any employer matching contributions, 43 percent take up the default. By comparison, at plans that offer at an LT plan, which makes the default less liquid, or that offer company stock, which is not available in the default, or that offer employer matching, the default election rate is only 21 percent. The presence or absence of the LT option appears to be the most substantively important of these factors.

There are important correlations between plan features, which makes simple bivariate analysis as in Figure 2 a starting rather than an ending point for analysis. Table 6 presents pairwise correlations between a number of plan attributes, as well as between the attributes such as age and gender of individual participants and the plan attributes. As the data in Table 5 suggested, while it raises a plan's complexity, the presence of an LT option is negatively correlated (-0.37) with the take-up of the plan's default option. The correlation between the presence of an LT option and firm matching is 0.48 and between an LT option and offering employer stock is 0.10 . The positive correlation between the LT saving option and the match could arise for two reasons. One is that firms differ in their degree of paternalism toward their workers, and that more paternalistic firms offer an LT option to promote retirement security, and also offer a match to enable workers to build retirement assets. The other is that management recognizes that some workers, especially those with low variable remuneration who expect future liquidity constraints, are averse to LT investments, and they offer an LT option as a way 
to reduce plan participation and the associated cost of their matching contributions while more effectively targeting those contributions to better-compensated workers.

\section{Table 6: Correlation Matrix for Worker and Plan Characteristics}

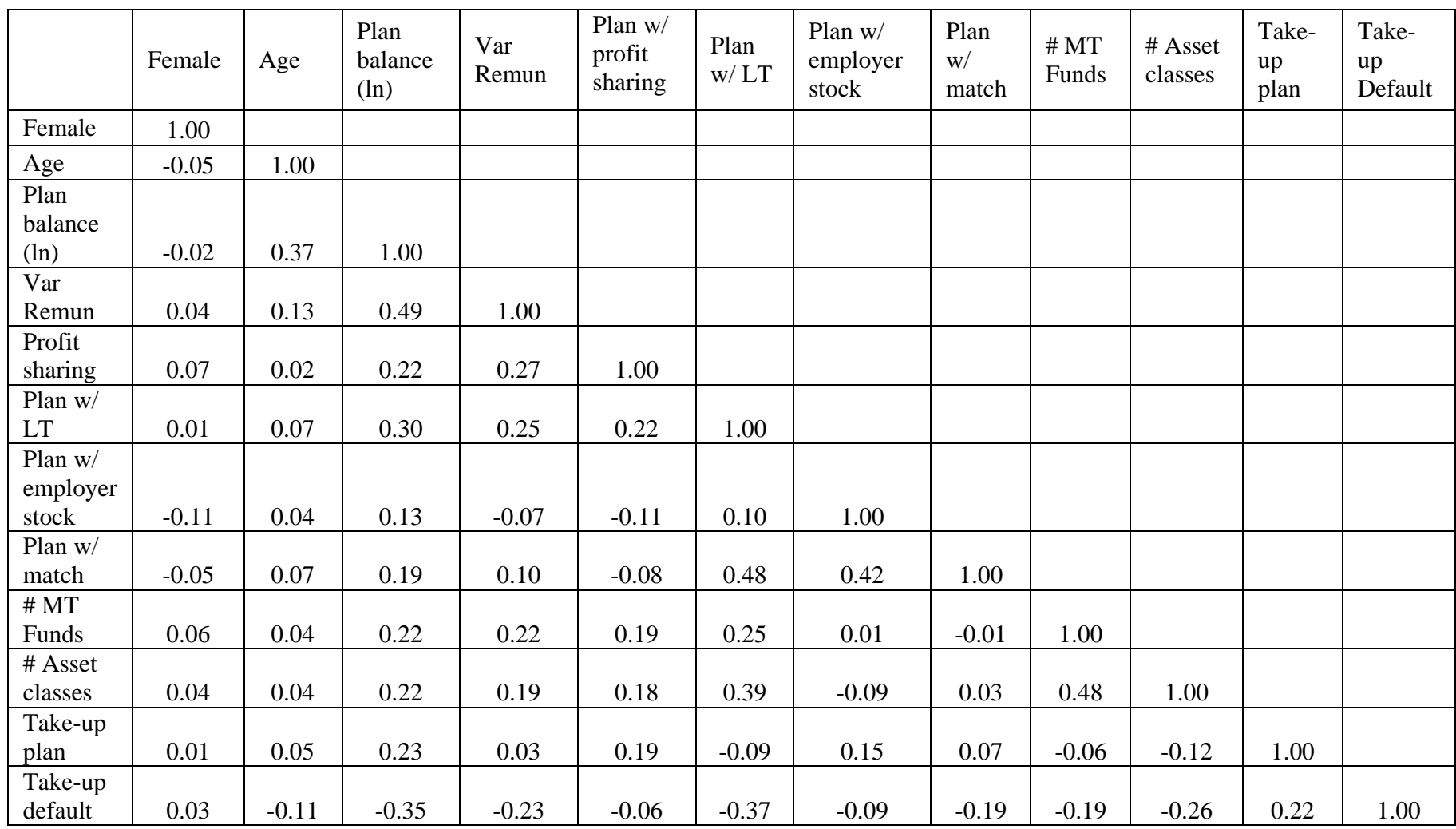

The correlation between offering company stock and offering a match is 0.42 . In our sample of 1,583 firms, 657 offer matching contributions. In this group, $47 \%$ of the firms, corresponding to $78 \%$ of the workers, offer company stocks and $62 \%$ of the firms offer a LT option. The correlation between offering company stock and offering a LT plan is only 0.10, well below some of the other pairwise correlations between plan attributes. The range of correlations underscores that firms may be motivated by a variety of competing objectives in designing saving plans for their workers.

The correlation between take-up of the plan and take-up of the default option is 0.22 . While 87 percent of eligible participants take up the plan, only about 25 percent take up the default option. There are positive correlations between the number of funds and the number of asset classes offered in the plan and the presence of a LT option, small negative correlations between both and the offering of employer stock as an investment option, and essentially no correlation with employer matching.

Table 7 presents additional comparisons between different types of plans, but rather than comparing the workers in these plans as in Table 5, it compares the median attributes across plans. 
This is a different way of weighting the participant information. In Table 5, the configuration of attributes at a firm with 10,000 employees would have 40 times as much weight as those at a firm with 250 employees. In Table 7, the two plans receive equal weight. There are some differences between the two tables. In Table 7, variable remuneration at firms that offer LT plans is about 26 percent greater than that at firms that do not offer such plans, a smaller difference than the employee-weighted difference in Table 5. This may be due in part to the focus on medians in Table 7, which reduces the influence of large positive outliers with respect to variable remuneration.

\section{Table 7: Comparison of Firms Offering Different Types of Saving Plans}

\begin{tabular}{|c|c|c|c|c|c|c|}
\hline & $\begin{array}{c}\text { Plan w/ } \\
\text { MT menu } \\
\mathrm{N}=1,038\end{array}$ & $\begin{array}{c}\text { Plan w/ } \\
\text { MT and LT } \\
\text { menu } \\
\mathrm{N}=545\end{array}$ & $\begin{array}{c}\text { Plan w/o } \\
\text { employer } \\
\text { stock } \\
\mathrm{N}=1219\end{array}$ & $\begin{array}{c}\text { Plan w/ } \\
\text { employer } \\
\text { stock } \\
\mathrm{N}=364\end{array}$ & $\begin{array}{c}\text { Plan w/o } \\
\text { match } \\
\mathrm{N}=926\end{array}$ & $\begin{array}{l}\text { Plan w/ } \\
\text { match } \\
\mathrm{N}=657\end{array}$ \\
\hline$\%$ of female employees & 0.40 & $0.38 * * *$ & 0.41 & $0.33 * * *$ & 0.40 & 0.39 \\
\hline $\begin{array}{l}\text { Median age of } \\
\text { employees }\end{array}$ & 44.92 & $46.86 * *$ & 45.09 & $47.27 * * *$ & 44.72 & $46.81^{* * *}$ \\
\hline $\begin{array}{l}\text { Ln (median total assets) } \\
(€)\end{array}$ & 8.13 & $8.71^{* * *}$ & 8.08 & $9.15^{* * *}$ & 7.89 & $8.95^{* * *}$ \\
\hline $\begin{array}{l}\text { Median variable } \\
\text { remuneration }(€)\end{array}$ & 1613.82 & $2040.30^{* * *}$ & 1698.02 & 1970.40 & 1425.19 & $2233.46^{* * *}$ \\
\hline Profit sharing & 0.65 & $0.60 *$ & 0.66 & $0.53^{* * *}$ & 0.71 & $0.52 * * *$ \\
\hline Plan w/ LT savings & & & 0.26 & $0.62 * * *$ & 0.15 & $0.62^{* * *}$ \\
\hline Plan w/employer stock & 0.13 & $0.41^{* * *}$ & & & 0.06 & $0.47 * * *$ \\
\hline Plan w/ match & 0.24 & $0.75^{* * *}$ & 0.29 & $0.84^{* * *}$ & & \\
\hline \# Funds in MT menu & 6.79 & $7.98^{* * *}$ & 7.05 & $7.71^{* *}$ & 6.79 & $7.77 * * *$ \\
\hline \# Asset classes & 2.68 & $3.36^{* * *}$ & 2.83 & $3.18^{* * *}$ & 2.73 & $3.17^{* * *}$ \\
\hline Take-up of the plan & 0.90 & $0.84 * * *$ & 0.89 & $0.83^{* * *}$ & 0.88 & 0.88 \\
\hline $\begin{array}{l}\text { Take-up of the default } \\
\text { option }\end{array}$ & 0.34 & $0.14^{* * *}$ & 0.32 & $0.11^{* * *}$ & 0.38 & $0.12^{* * *}$ \\
\hline
\end{tabular}

The summary statistics on take-ups are similar when we average across firms and when we average across individuals. The fraction of firms that offer employer stock funds (23\%) or matching contributions (41\%) is smaller than the fraction of workers who are offered these plan features. The fraction of plans offering employer stock (13\%) and matching contributions (24\%) as part of MT-only plans is also much smaller than the proportions of employees who receive such opportunities (60\% and 
45\% respectively). This indicates that company stock and matching in MT-only plans are offered primarily by larger firms. This makes sense for company stock, since the largest firms in our sample are listed on the stock market. Large firms that design MT+LT plans may be more likely to offer matching contributions to their employees as an incentive to invest in LT savings. This generates some overlap between the presence of the match and LT saving plans and makes it difficult to disentangle their respective impacts. We address this below by interacting the presence of LT savings in the plan menu with indicator variables for the participant's proximity to retirement, which determines the relative liquidity of MT and LT savings. Workers over the age of 62, for example, are less than five years away from retirement, so for them, a five-year MT investment is less liquid than an LT investment that can be drawn down at retirement.

\subsection{Analysis of Plan Take-up}

All French saving plans feature automatic enrollment, so an individual who takes no action following the annual announcement of variable remuneration and the plan menu is enrolled and invested in the default option. To study the impact of plan attributes on employee decisions to participate and to accept the plan default asset allocation, we estimate linear probability models for each decision. The set of explanatory variables are the same for both decisions. We report standard errors clustered by firm, reflecting the variation at the firm level in the savings plan design. This conservative clustering choice yields larger standard errors than alternatives such as firm x region clustering, which could be justified by the observation that large firms in our sample have workers in multiple regions. Workers in different places face different costs of living and different labor market conditions.

Table 8 reports results for the participation decision. In the first column, the only explanatory variables are worker gender, age, and the worker's position (quantile) in the firm's variable remuneration distribution. Workers over the age of 62 are about 2.5 percent more likely to participate than those between the ages of 58 and 61, who are in turn about 2.4 percent more likely to participate than those who are 57 or younger. We choose these age cutoffs to recognize that for some workers, MT savings are less liquid than LT savings (blocked until retirement), because expected retirement is in less than five years. In our sample, $82 \%$ of workers are under the age of 57 , and have at least five years of work remaining before they reach retirement age. For them, MT plan contributions can be

accessed earlier than LT plan contributions. Only 4 percent of the sample is over the age of 62, the age at which access to both MT and LT plan assets becomes equal. For the omitted category of workers 
between 57 and 62 of age, there is ambiguity since workers in France can retire at any time between ages 62 and 67 depending on the duration of their work career. Women are about two percent more likely to participate than men, and there is a gradient in the variable remuneration quartile. Those in the two bottom quartiles are about five percent less likely to participate than those in the top quartile. This may be because higher tax rates, associated with higher variable remuneration, raise the tax incentive for plan participation. Likewise, employees at firms that offer profit sharing benefits are more likely to participate that those who do not.

\section{Table 8: Plan Attributes and Plan Take-Up}

\begin{tabular}{|c|c|c|c|c|c|c|}
\hline & (1) & (2) & (3) & (4) & (5) & (6) \\
\hline Plan w/ LT savings & & $\begin{array}{c}-0.095 * * \\
(0.048)\end{array}$ & & & $\begin{array}{c}-0.16^{* * * *} \\
(0.046)\end{array}$ & $\begin{array}{c}-0.13 * * * \\
(0.041)\end{array}$ \\
\hline Plan w/ employer stock & & & $\begin{array}{c}0.12 * * * \\
(0.034)\end{array}$ & & $\begin{array}{c}0.10^{* * *} \\
(0.026)\end{array}$ & $\begin{array}{c}0.10^{* * *} \\
(0.025)\end{array}$ \\
\hline Plan w/ match & & & & $\begin{array}{l}0.066^{*} \\
(0.039)\end{array}$ & $\begin{array}{c}0.11^{* * *} \\
(0.038)\end{array}$ & $\begin{array}{c}0.098^{* * *} \\
(0.035)\end{array}$ \\
\hline Age $<=57$ & $\begin{array}{c}-0.032^{* * *} \\
(0.0074)\end{array}$ & $\begin{array}{c}-0.036 * * * \\
(0.0074)\end{array}$ & $\begin{array}{c}-0.028^{* * *} \\
(0.0065)\end{array}$ & $\begin{array}{c}-0.026^{* * *} \\
(0.0072)\end{array}$ & $\begin{array}{c}-0.031^{* * *} \\
(0.0069)\end{array}$ & $\begin{array}{c}-0.032^{* * * *} \\
(0.0071)\end{array}$ \\
\hline Age $>=62$ & $\begin{array}{c}0.032 * * * \\
(0.012)\end{array}$ & $\begin{array}{c}0.023 * * * \\
(0.0079)\end{array}$ & $\begin{array}{l}0.019 * * \\
(0.0095)\end{array}$ & $\begin{array}{l}0.020^{* *} \\
(0.0095)\end{array}$ & $\begin{array}{c}0.026 * * * \\
(0.0072)\end{array}$ & $\begin{array}{c}0.030 * * * \\
(0.0068)\end{array}$ \\
\hline Female & $\begin{array}{c}0.013 \\
(0.015)\end{array}$ & $\begin{array}{l}0.0027 \\
(0.013)\end{array}$ & $\begin{array}{c}0.016 \\
(0.010)\end{array}$ & $\begin{array}{l}0.0060 \\
(0.013)\end{array}$ & $\begin{array}{l}0.018^{*} \\
(0.010)\end{array}$ & $\begin{array}{l}0.020^{* *} \\
(0.0098)\end{array}$ \\
\hline Variable remuneration in Q1 & $\begin{array}{c}-0.11^{* * * *} \\
(0.025)\end{array}$ & $\begin{array}{c}-0.089 * * * \\
(0.020)\end{array}$ & $\begin{array}{c}-0.095^{* * * *} \\
(0.020)\end{array}$ & $\begin{array}{c}-0.096 * * * \\
(0.019)\end{array}$ & $\begin{array}{c}-0.090 * * * \\
(0.019)\end{array}$ & $\begin{array}{c}-0.091 * * * \\
(0.019)\end{array}$ \\
\hline Variable remuneration in Q2 & $\begin{array}{c}-0.070^{* * *} \\
(0.018)\end{array}$ & $\begin{array}{c}-0.061^{* * *} \\
(0.016)\end{array}$ & $\begin{array}{c}-0.065^{* * *} \\
(0.016)\end{array}$ & $\begin{array}{c}-0.070^{* * *} \\
(0.014)\end{array}$ & $\begin{array}{c}-0.062 * * * \\
(0.015)\end{array}$ & $\begin{array}{c}-0.064^{* * *} \\
(0.014)\end{array}$ \\
\hline Variable remuneration in Q3 & $\begin{array}{c}-0.026^{*} \\
(0.014)\end{array}$ & $\begin{array}{c}-0.025^{*} \\
(0.014)\end{array}$ & $\begin{array}{c}-0.029^{* *} \\
(0.014)\end{array}$ & $\begin{array}{c}-0.033^{* * *} \\
(0.012)\end{array}$ & $\begin{array}{c}-0.029^{* *} \\
(0.012)\end{array}$ & $\begin{array}{c}-0.032^{* * * *} \\
(0.011)\end{array}$ \\
\hline Profit sharing & & $\begin{array}{c}0.14^{* * *} \\
(0.048)\end{array}$ & $\begin{array}{c}0.13^{* * *} \\
(0.049)\end{array}$ & $\begin{array}{l}0.13^{* *} \\
(0.054)\end{array}$ & $\begin{array}{c}0.17 * * * \\
(0.030)\end{array}$ & $\begin{array}{c}0.18^{* * *} \\
(0.027)\end{array}$ \\
\hline \# Funds in MT plan & & & & & & $\begin{array}{c}-0.0018 \\
(0.0025)\end{array}$ \\
\hline \# Asset classes & & & & & & $\begin{array}{c}-0.031 * * \\
(0.016)\end{array}$ \\
\hline Constant & $\begin{array}{c}0.94 * * * \\
(0.016)\end{array}$ & $\begin{array}{l}0.90^{* * *} \\
(0.058)\end{array}$ & $\begin{array}{c}0.77^{* * *} \\
(0.032)\end{array}$ & $\begin{array}{c}0.82^{* * *} \\
(0.036)\end{array}$ & $\begin{array}{c}0.77^{* * *} \\
(0.024)\end{array}$ & $\begin{array}{c}0.87^{* * *} \\
(0.059)\end{array}$ \\
\hline R-squared & 0.018 & 0.067 & 0.078 & 0.057 & 0.118 & 0.125 \\
\hline
\end{tabular}

*** $\mathrm{p}<0.01,{ }^{* *} \mathrm{p}<0.05, * \mathrm{p}<0.1$. All equations are estimated on 645,966 individual observations.

Columns two through four include, sequentially, each of our three “essential” plan attributes: LT savings, employer stock, and the presence of an employer match. The fifth column includes all three of these plan attributes, and the final column expands on that specification by including two measures of the range of investment options available in the plan. The most salient result is the negative association between the presence of LT savings in the plan menu and the take-up rate. The estimates 
in columns (5) and (6), which control for other plan attributes, suggest a negative participation effect of between 13 and 16 percentage points. The negative coefficient on plan take-up suggests that even though offering an LT savings plan represents an additional opportunity for workers, employees prefer participating in LT-free plans. This may reflect an aversion on the part of some workers to undertaking the decision-making that is required to opt out of the default investment option and to evaluate the plan's full menu of investment choices. Opting out of the plan may be the easiest way to avoid both LT savings and the burden of making complex choices.

The results in specifications (3), (5), and (6) suggest that the presence of employer stock in the menu of plan investments is associated with a positive effect of between 10 and 12 percentage points on plan participation. Employer matching contributions are also associated with higher participation rates, with the point estimates varying from 6 to 11 percentage points. The coefficients on the worker attributes, age, gender, and rank in the variable remuneration distribution, are relatively insensitive to the inclusion of the three plan attributes of interest. All of the reported equations have relatively low explanatory power. This may reflect in part the high overall participation rate in most plans, and the somewhat idiosyncratic nature of many decisions not to participate.

\subsection{Analysis of Take-up of the Default Option}

Table 9 examines the take-up of the default option by employees who are offered saving plans. The sample for the default equations is the same as for the participation equation; the dependent variable is not default participation conditional on plan participation, but default participation conditional on being offered a plan. This facilitates comparisons between the results in Tables 8 and 9. The overall participation rate for our sample is nearly 90 percent; 25 percent of all employees who are offered a saving plan elect the default investment allocation.

The estimated association between the three "essential" plan attributes and the take-up of the default is sensitive to the choice of other covariates in the specification. This was not true for the participation equations reported in Table 8. The specifications (5) and (6), which include all three plan attributes, indicate a negative association between the presence of LT savings in the plan menu and the take-up of the plan's default option. The estimates imply a negative impact of between 26 and 32 percentage points on the participation rate. If, as we suggest above, some workers dislike the illiquid nature of LT savings, they must opt out of the default to avoid such investments. 
Table 9: Take-up of the Default

\begin{tabular}{|c|c|c|c|c|c|c|}
\hline & (1) & (2) & (3) & (4) & (5) & (6) \\
\hline Plan w/ LT savings & & $\begin{array}{c}-0.32 * * * \\
(0.069)\end{array}$ & & & $\begin{array}{c}-0.32 * * * \\
(0.11)\end{array}$ & $\begin{array}{c}-0.26^{* * *} \\
(0.085)\end{array}$ \\
\hline Plan w/ employer stock & & & $\begin{array}{l}-0.086 \\
(0.076)\end{array}$ & & $\begin{array}{l}-0.049 \\
(0.059)\end{array}$ & $\begin{array}{l}-0.051 \\
(0.057)\end{array}$ \\
\hline Plan w/ match & & & & $\begin{array}{c}-0.18^{* *} \\
(0.086)\end{array}$ & $\begin{array}{l}0.016 \\
(0.11)\end{array}$ & $\begin{array}{l}-0.013 \\
(0.092)\end{array}$ \\
\hline Age $<=57$ & $\begin{array}{c}0.045^{* * *} \\
(0.014)\end{array}$ & $\begin{array}{l}0.027^{*} \\
(0.015)\end{array}$ & $\begin{array}{c}0.043^{* * *} \\
(0.014)\end{array}$ & $\begin{array}{c}0.034 * * * \\
(0.011)\end{array}$ & $\begin{array}{c}0.027^{* *} \\
(0.013)\end{array}$ & $\begin{array}{l}0.024^{*} \\
(0.013)\end{array}$ \\
\hline Age $>=62$ & $\begin{array}{l}-0.015 \\
(0.035)\end{array}$ & $\begin{array}{l}0.0037 \\
(0.013)\end{array}$ & $\begin{array}{l}-0.0090 \\
(0.022)\end{array}$ & $\begin{array}{l}-0.011 \\
(0.021)\end{array}$ & $\begin{array}{l}0.0041 \\
(0.011)\end{array}$ & $\begin{array}{c}0.013 \\
(0.0083)\end{array}$ \\
\hline Female & $\begin{array}{c}0.029 \\
(0.035)\end{array}$ & $\begin{array}{l}0.033^{*} \\
(0.019)\end{array}$ & $\begin{array}{c}0.024 \\
(0.023)\end{array}$ & $\begin{array}{c}0.025 \\
(0.023)\end{array}$ & $\begin{array}{l}0.028^{*} \\
(0.015)\end{array}$ & $\begin{array}{c}0.033^{* *} \\
(0.014)\end{array}$ \\
\hline Variable remuneration in Q1 & $\begin{array}{c}0.012 \\
(0.017)\end{array}$ & $\begin{array}{l}0.022^{*} \\
(0.012)\end{array}$ & $\begin{array}{l}0.0066 \\
(0.014)\end{array}$ & $\begin{array}{c}0.011 \\
(0.013)\end{array}$ & $\begin{array}{l}0.022^{*} \\
(0.012)\end{array}$ & $\begin{array}{c}0.020 \\
(0.012)\end{array}$ \\
\hline Variable remuneration in Q2 & $\begin{array}{l}-0.0081 \\
(0.019)\end{array}$ & $\begin{array}{l}0.0086 \\
(0.015)\end{array}$ & $\begin{array}{l}-0.010 \\
(0.018)\end{array}$ & $\begin{array}{c}-0.00068 \\
(0.012)\end{array}$ & $\begin{array}{l}0.0076 \\
(0.015)\end{array}$ & $\begin{array}{l}0.0033 \\
(0.015)\end{array}$ \\
\hline Variable remuneration in Q3 & $\begin{array}{l}-0.011 \\
(0.023)\end{array}$ & $\begin{array}{l}0.0039 \\
(0.018)\end{array}$ & $\begin{array}{l}-0.0096 \\
(0.024)\end{array}$ & $\begin{array}{c}0.00021 \\
(0.018)\end{array}$ & $\begin{array}{l}0.0034 \\
(0.016)\end{array}$ & $\begin{array}{l}-0.0029 \\
(0.016)\end{array}$ \\
\hline Profit sharing & & $\begin{array}{c}0.020 \\
(0.074)\end{array}$ & $\begin{array}{l}-0.058 \\
(0.12)\end{array}$ & $\begin{array}{l}-0.063 \\
(0.13)\end{array}$ & $\begin{array}{c}0.017 \\
(0.060)\end{array}$ & $\begin{array}{c}0.030 \\
(0.049)\end{array}$ \\
\hline \# Funds in MT plan & & & & & & $\begin{array}{c}-0.0062 * \\
(0.0034)\end{array}$ \\
\hline \# Asset classes & & & & & & $\begin{array}{l}-0.063^{*} \\
(0.032)\end{array}$ \\
\hline Constant & $\begin{array}{c}0.20^{* * *} \\
(0.065)\end{array}$ & $\begin{array}{c}0.36^{* * *} \\
(0.11)\end{array}$ & $\begin{array}{l}0.29 * * * \\
(0.091)\end{array}$ & $\begin{array}{l}0.36^{* * *} \\
(0.099)\end{array}$ & $\begin{array}{c}0.38^{* * *} \\
(0.063)\end{array}$ & $\begin{array}{c}0.60 * * * \\
(0.13)\end{array}$ \\
\hline R-squared & 0.003 & 0.138 & 0.015 & 0.043 & 0.141 & 0.162 \\
\hline
\end{tabular}

*** $\mathrm{p}<0.01,{ }^{* *} \mathrm{p}<0.05,{ }^{*} \mathrm{p}<0.1$. All equations are estimated on 645,966 individual observations.

The presence of employer stock in the plan, which was associated with higher participation in Table 8, is associated with a statistically insignificantly lower rate of default take-up. ${ }^{13}$ A negative coefficient is consistent with employer stock being attractive and requiring employees to opt-out of the default to gain access.

The estimated effect of employer matching does not have a statistically significant effect on default take-up when the linear probability model includes a rich set of other plan attributes. This may indicate that the match is not an essential plan attribute, or it may suggest that matching contributions are typically available in the default as well as on non-default investments, and that decisions about

\footnotetext{
${ }^{13}$ This result is sensitive to our choice of clustering for standard errors. With firm $\mathrm{x}$ region clustering, the estimated negative effect is statistically significantly different from zero. It is not with firm clustering of the standard errors, as reported in Table 9.
} 
whether to accept the default investment allocation are therefore not affected very much by the presence or absence of a match.

With respect to other plan attributes in the specification, the number of investment funds on the plan menu has a negative, but small, association with default take-up. The number of asset classes represented by the plan investment options has a larger negative effect. We have not tried to construct the efficient portfolio frontier that a participant could access as a result of the set of fund offerings in each plan, but we conjecture that the number of funds and asset classes offered are positively correlated with the feasible degree of portfolio diversification. The pattern of coefficients suggests that participants are less likely to accept the default when the plan offers a richer investment menu. There is some tension between the results for the participation and default take-up equations. The former, which show that a larger number of asset classes on the plan platform is associated with lower take-up, is consistent with the view offered by Iyengar and Lepper (2000) and Iyengar, Huberman, and Jiang (2004) that a larger number of funds represents a greater choice burden for participants and may discourage plan take-up. The greater likelihood of opting out of the default when there is a richer menu of investment options, however, suggests that if they participate, workers are not driven to the default allocation by a larger number of investment choices. The level of variable remuneration is negatively associated with take-up of the default. Employees in the bottom quartile are about 3 percentage points more likely to accept the default than those in the top quartile. This may reflect different levels of investment knowledge and sophistication, or different valuation of portfolio customization. Women are about 3 percentage points more likely than men to accept the plan default.

\subsection{Age-Related Differences in Liquidity of MT and LT Plans}

The strong association of LT investment offerings on both plan participation and default take-up motivates some additional exploration. We focus on the age-related disparities in the relative liquidity of MT and LT investment options. As noted above, relative to those over the age of 58, for individuals who are aged 57 and younger and therefore at least five years away from retirement, the time until assets in an LT account can be accessed is unambiguously longer than the time until MT investments can be. In contrast, for those over 62, both MT and LT investments can be accessed at retirement; they exhibit the same liquidity.

To study the effect of age on the estimated effects of plans offering LT investment options, we stratify our sample of participants into five-year age groups. We use the group of "62 and above” as the control group and remove the 57-61 group from the sample because the liquidity of LT options for 
this group is unclear due to the uncertainty of their retirement age. Then, we estimate linear probability models with specifications similar to those reported in column (5) of Tables 8 and 9, respectively, but we interact the more granular age class indicator variables with the variable flagging the presence of an LT option in the plan. Figure 3 plots the resulting coefficients and associated standard error bands. If aversion to illiquid investments is a driver of the estimated effect of the LT option variable on plan participation, we would expect the effect to be most negative for the youngest age groups.

\section{Figure 3: Age-Group Specific Impact of LT Option on Plan Participation (left) and Take-up of Plan Default Option (right)}
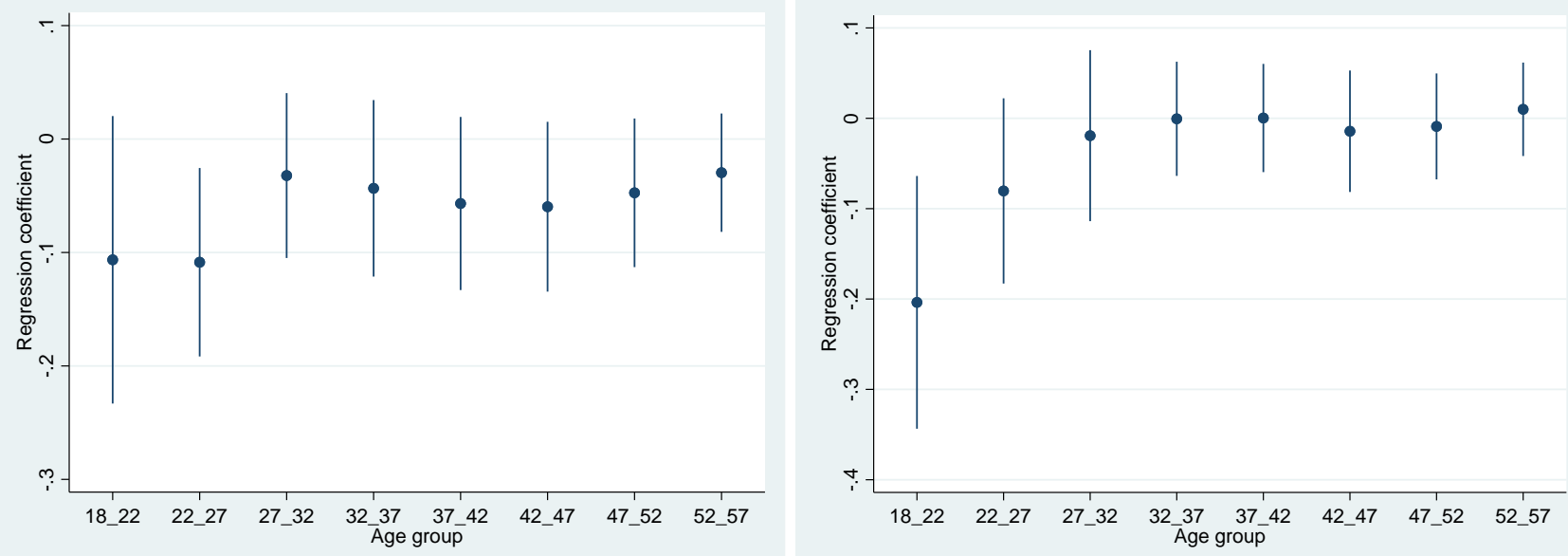

The findings suggest that younger workers (below 27) are more LT-plan-averse, and more likely to forego participating in a plan with an LT option, than their older colleagues. It is nevertheless difficult to distinguish differential effects of offering an LT option on the participation rates of workers between ages 27 and 57. The negative impact on the take-up of the default option is also particularly strong for the youngest group. The group aged 62 and older is the control group. The results in the figures confirm the estimate in Table 8 that, regardless of the presence of an LT savings option, workers below age 57 exhibit lower overall participation than their colleagues aged 58 and above.

\section{Conclusion}

This paper exploits a rich administrative data set on participants in French retirement saving plans, along with the substantial variation in the structure of these plans, to investigate the association between various plan provisions and participant behavior. It views participant choices through the lens of behavioral economics, recognizing that the complexity of some retirement plans may pose decisionmaking challenges for some participants. All employer-provided retirement saving plans in France feature automatic enrollment. A worker who follows the enrollment default, and accepts the default 
asset allocation, does not need to master the details of the plan and can thereby avoid the burden of decision-making.

Offering LT saving options affects a plan's default, since regulations require that any plan with profit sharing and a LT option must include that option in its default. Individuals who demand precautionary liquidity and are not prepared to exert the decision effort that is needed to select investment options other than the default may choose to opt out of the plan entirely, rather than to participate and opt-out of the default investment option.

Together, precautionary liquidity and choice overload offer a conceptual framework that can explain our empirical findings. By contrast, regarding the two other essential attributes - company stock and match - the attractiveness of these two features is strong enough to increase plan participation despite the fact that their presence pushes workers toward opting out the default option, suggesting that choice overload alone fails to catch the French evidence.

Our analysis focuses on two decisions by workers who are offered employer-sponsored retirement plans: participation in the plan, and acceptance of the asset-allocation default. The participation rate in employer-sponsored plans in France is high - almost 90 percent in our sample and it is related to the three plan attributes that we describe as “essential:" the presence of an illiquid investment option, the availability of company stock as an investment option, and the presence of a company matching contribution. The employee participation rate is about six percentage points lower in plans that offer a long-term investment option than in those that do not, and it is about five percentage points higher in plans that offer company stock investments. The presence of an employer matching contribution is associated with a six percent higher participation rate. A number of other plan attributes, such as the number of investment options offered and the range of asset classes available to investors, are not substantively important predictors of participation decisions.

The likelihood of a participant accepting the default asset allocation is also correlated with the presence of an illiquid investment option and the availability of employer stock. When a plan, and therefore its default option, offer an illiquid investment option, participants are 16 percentage points more likely to opt out of the default than when the default does not include an illiquid investment. When the plan includes company stock, which cannot be included in the default, participants are eight percentage points more likely to opt out of the default. We do not find a strong association between matching contributions and either participation or default take-up. This may be because our matching measure is incomplete. An employer may match some or all the investment options in the default and 
the plan more generally. We find that participants are about four percentage points more likely to opt out of the default at firms that offer employer matching contributions on one or more investment option, but it is difficult to reject the null hypothesis of no effect.

Our findings are consistent with participation decisions depending in part on the menu of investment options in the plan. When there are options that some workers would prefer to avoid illiquid long-term investments - some workers choose not to participate at all, while others opt out of the default that includes these options. Similarly, the presence of an attractive investment option company stock - can increase plan take-up, even when it is not part of the default and requires an active investment election. The negative association between offering an illiquid option and participation is consistent with behavioral models of decision-making. When learning about the plan and making optimal investment choices is costly, some participants may forego the tax and matching contribution benefits of plan participation to avoid these costs. They, and other, employees may employ decision heuristics, perhaps focusing on a few "essential” plan attributes, to guide their choices.

Some of our findings, such as the relatively modest association between employer matching contributions and plan participation rates, are broadly consistent with a number of previous studies. Our finding of a negative association between the presence of an illiquid investment option in the plan and its default asset allocation, and the rates of plan participation and take-up of the default, suggests reluctance on the part of some employees to forego access to their account balances until retirement. This finding bears on recent research suggesting that households have a demand for commitment devices such as long-term saving plans that prevent them from prematurely withdrawing assets from their retirement account. In the French context, it appears that the presence of such long-term restrictions on liquidity on balance reduced voluntary plan participation. 


\section{References}

Agnew, J., P. Balduzzi, P., and A. Sunden (2003). Portfolio choice and trading in a large 401 (k) plan. American Economic Review 93(1), 193-215.

Ambuehl, S., B.D. Bernheim, and A. Ockenfels (2021). What Motivates Paternalism? An Experimental Study. American Economic Review 111(3): 787-830.

Andersen, H. Y. (2018). Do tax incentives for saving in pension accounts cause debt accumulation? Evidence from Danish register data. European Economic Review 106: 35-53.

Bhargava, S. and D. Manoli (2015). Psychological frictions and the incomplete take-up of social benefits: Evidence from an IRS field experiment. American Economic Review 105(11): 3489-3529.

Benarzi, S. (2001). Excessive extrapolation and the allocation of 401 (k) accounts to company stock. Journal of Finance 56(5), 1747-1764.

Besedeš, T., C. Deck, S. Sarangi, and M. Shor (2015). Reducing choice overload without reducing choices. Review of Economics and Statistics 97(4), 793-802.

Beshears, J., J.J. Choi, C. Clayton, C. Harris, D. Laibson, and B.C. Madrian (2020). Optimal illiquidity. NBER working paper 27459.

Beshears, J., J.J. Choi, D. Laibson, and B.C. Madrian (2009). The importance of default options for retirement saving outcomes: Evidence from the United States. In Brown, J. R., J.B. Liebman, and D.A. Wise (Eds.). Social Security Policy in a Changing Environment. University of Chicago Press, 167-195.

Beshears, J., J.J. Choi, D. Laibson, and B.C. Madrian (2010). The impact of employer matching on savings plan participation under automatic enrollment. In Research Findings in The Economics of Aging (pp. 311-327). University of Chicago Press.

Beshears, J., J.J. Choi, D. Laibson, and B.C. Madrian (2017). Does aggregated returns disclosure increase portfolio risk taking? Review of Financial Studies 30(6): 1971-2005.

Beshears, J., J.J. Choi, D. Laibson, and B.C. Madrian (2021). Active choice, implicit defaults, and the incentive to choose. Organizational Behavior and Human Decision Processes. 163: 6-16.

Booij, A.S., E. Leuven, and H. Oosterbeek (2012). The role of information in the take-up of student loans. Economics of Education Review 31(1): 33-44.

Brown, J.R., N. Liang, and S. Weisbenner (2007). Individual account investment options and portfolio choice: Behavioral lessons from 401(k) plans. Journal of Public Economics 91(10): 1992-2013.

Briere, Marie, James Poterba and Ariane Szafarz (2022). Precautionary liquidity and retirement saving. American Economic Review: Papers and Proceedings.

Bubb, R., P.M. Corrigan, and P.L. Warren (2015). A behavioral contract theory perspective on retirement savings. Connecticut Law Review 15-06.

Bubb, R. and P.L. Warren (2020). An equilibrium theory of retirement plan design. American Economic Journal: Economic Policy 12(2): 22-45.

Butrica, B.A., and N.S. Karamcheva (2015). Automatic enrollment, employer match rates, and employee compensation in 401 (k) plans. Monthly Labor Review 138, 1. 
Caplin, A. and D. Martin (2015). A testable theory of imperfect perception. Economic Journal 125(582): 184-202.

Cardella, Eric, Charlene Kalenkoski, and Michael Parent (2021). Less is not more: 401(k) plan information and retirement planning choices. Journal of Pension Economics and Finance, 1-21.

Chetty, R., J.N. Friedman, S. Leth-Petersen, T. Heien, and N. T. Olsen (2014). Active vs. passive decisions and crowd-out in retirement savings accounts: Evidence from Denmark. Quarterly Journal of Economics 129 (3): 1141-1219.

Choi, J.J., E. Haisley, J. Kurkoski, and C. Massey (2017). Small cues change savings choices. Journal of Economic Behavior \& Organization 142: 378-395.

Choi, J.J., D. Laibson, D., and B.C. Madrian (2011). \$100 bills on the sidewalk: Suboptimal investment in 401(k) plans. Review of Economics and Statistics 93(3): 748-763.

Choi, J.J., D. Laibson, D., B.C. Madrian, and A. Metrick (2002). Defined contribution pensions: Plan rules, participant choices, and the path of least resistance. Tax policy and the Economy, 16: 67-113.

Choi, J.J., D. Laibson, D., B.C. Madrian, and A. Metrick (2004). For better or for worse: Default effects and 401 (k) savings behavior. In Perspectives on the Economics of Aging (pp. 81-126), University of Chicago Press.

Clark, J.W. and J.A. Young (2018). Automatic enrollment: The power of the default, Vanguard Research, March.

Cribb, J., and C. Emmerson (2020). What happens to workplace pension saving when employers are obliged to enroll employees automatically? International Tax and Public Finance 27: 664-693.

Dahlquist M., O. Setty, and R. Vestman (2018) On the asset allocation of a default pension fund, Journal of Finance 73(4): 1893-1936.

Direction de l'Animation de la Recherches, des Etudes et des Statistiques (DARES) (2018). Participation, intéressement et épargne salariale en 2016 : Les sommes distribuées aux salariés progressent pour la troisième année consécutive, DARES Résultats 40, August.

Duflo, E. and E. Saez (2003). The role of information and social interactions in retirement plan decisions: Evidence from a randomized experiment. Quarterly Journal of Economics 118(3): 815842.

Dworak-Fisher, K. (2011). Matching matters in 401 (k) plan participation. Industrial Relations 50(4): 713-737.

Engelhardt, G.V. and A. Kumar (2007). Employer matching and 401(k) saving: Evidence from the health and retirement study. Journal of Public Economics 91(10): 1920-1943.

Engelhardt, G.V. and A. Kumar (2008). Money on the table: Some evidence on the role of liquidity constraints in 401(k) saving. Economics Letters 99, 2, 402-404.

Even, W.E. and D.A. Macpherson (2005). The effects of employer matching in 401(k) plans. Industrial Relations 44(3): 525-549.

Falk, J. and N. Karamcheva (2019). The effect of the employer match and defaults on Federal workers' savings behavior in the thrift savings plan, WP Congressional Budget Office. 
Houser, D., D. Schunk, D., J. Winter, and E. Xiao (2018). Temptation and Commitment in the Laboratory. Games and Economic Behavior 107: 329-344.

Huang, L. and H. Liu (2007). Rational inattention and portfolio selection. Journal of Finance 62(4): 1999-2040.

Huberman, G., and W. Jiang (2006). Offering versus choice in 401 (k) plans: Equity exposure and number of funds. Journal of Finance 61(2): 763-801.

Huberman, G. and P. Sengmueller (2004). Performance and employer stock in 401(k) plans. Review of Finance 8(3): 403-443.

Iyengar, S.S., Huberman, G., and W. Jiang (2004). How much choice is too much? Contributions to 401 (k) retirement plans. In Mitchell, O.S. S.P. Utkus (Eds.) Pension Design and Structure: New Lessons from Behavioral Finance, pp. 83-96.

Iyengar, S.S., and M.R. Lepper (2000). When choice is demotivating: Can one desire too much of a good thing? Journal of Personality and Social Psychology 79(6): 995-1006.

Köszegi, B., and F. Matějka (2020). Choice simplification: A theory of mental budgeting and naive diversification. Quarterly Journal of Economics 135(2): 1153-1207.

Laibson, D. (2015). Why don't present-biased agents make commitments? American Economic Review 105(5): 267-72.

Madrian, B.C. and D.F. Shea (2001). The power of suggestion: Inertia in 401 (k) participation and savings behavior. Quarterly Journal of Economics 116(4): 1149-1187.

Madrian, B.C. (2012) Matching contributions and savings outcomes: A behavioral economics perspective. In R. Hintz, R. Hotzmann, D. Tuesta and N. Takayama (Eds.) Matching Contributions for Pensions: A Review of International Experience, Washington, D.C.: The World Bank, pp. 289310.

McDonald, Robert, David Richardson, and Thomas Rietz (2021). Investment defaults and retirement savings allocations. Mimeo, Department of Finance, Kellogg School of Management, Northwestern University.

Oprea, R. (2020). What Makes a Rule Complex? American Economic Review 110 (12): 3913-51.

Papke, L.E., and J.M. Poterba (1995). Survey evidence on employer match rates and employee saving behavior in 401(k) plans. Economics Letters 49(3): 313-317.

Poterba, J.M. (2003). Employer stock and 401 (k) plans. American Economic Review 93(2): 398-404.

Saez, E. (2009). Details matter: The impact of presentation and information on the take-up of financial incentives for retirement saving. American Economic Journal: Economic Policy 1(1): 204-228.

Schwartz, B. (2004). The Paradox of Choice: Why More is Less. New York: Ecco.

Scheibehenne, B., R. Greifeneder, and P.M. Todd (2010) Can there ever be too many options? A metaanalytic review of choice overload, Journal of Consumer Research, 37(3), 409-425.

Tse, A., Friesen, L., and K. Kalayc1 (2016). Complexity and asset legitimacy in retirement investment. Journal of Behavioral and Experimental Economics, 60, 35-48. 


\section{Appendix A: Comparison of Defined Contribution Plan Structures in US and France}

\begin{tabular}{|c|c|c|c|}
\hline & US Employer-Sponsored 401(k) & $\begin{array}{l}\text { France: MT } \\
\text { Plan (PEE) }\end{array}$ & $\begin{array}{l}\text { France: LT Plan } \\
\text { (PERCO) }\end{array}$ \\
\hline $\begin{array}{l}\text { Must employers } \\
\text { offer? }\end{array}$ & No - always optional & $\begin{array}{l}\text { Mandatory for } \\
\text { firms with over } \\
50 \text { employees }\end{array}$ & No \\
\hline Enrollment & $\begin{array}{l}\text { Voluntary enrollment but auto-enrollment } \\
\text { with opt-out increasingly common }\end{array}$ & \multicolumn{2}{|c|}{$\begin{array}{l}\text { Auto-enrollment directing variable } \\
\text { remuneration to default option }\end{array}$} \\
\hline Default option & $\begin{array}{c}\text { “Qualified Default Investment } \\
\text { Alternatives” (QDIAs) offer employer } \\
\text { safe-harbor for four default investment } \\
\text { options: target date funds, professionally- } \\
\text { managed accounts for plan participants, } \\
\text { balanced funds, and money market fund } \\
\text { (only for 120 days) }\end{array}$ & $\begin{array}{l}\text { Restricted to } \\
\text { money market, } \\
\text { bond, or } \\
\text { balanced funds }\end{array}$ & $\begin{array}{l}\text { Restricted to } \\
\text { balanced fund for } \\
\text { investment option; } \\
\text { allocation to LT in } \\
\text { default may be } \\
\text { between } 0 \text { and } 50 \%\end{array}$ \\
\hline Tax treatment & $\begin{array}{l}\text { Two variants: “traditional 401(k)" involves } \\
\text { pre-tax contributions with withdrawals } \\
\text { taxed as ordinary income; "Roth } 401(\mathrm{k}) \\
\text { involves post-tax contributions, } \\
\text { withdrawals are not taxed }\end{array}$ & \multicolumn{2}{|c|}{$\begin{array}{l}\text { Pre-tax contributions, withdrawals } \\
\text { taxed at } 8 \% \text { (compared to up to } 45 \% \\
\text { for wage earnings) plus variable cash- } \\
\text { out tax }\end{array}$} \\
\hline Maximal amount & $\begin{array}{l}\text { \$19,500 employee contribution, additional } \\
\$ 6500 \text { for those } 50 \text { and older, in } 2021 . \\
\text { Employer match plus employee } \\
\text { contribution must be }<\$ 58000 \\
\end{array}$ & \multicolumn{2}{|c|}{$€ 19,866$ (tax year 2017) } \\
\hline $\begin{array}{l}\text { Any limit on } \\
\text { number of funds? }\end{array}$ & No limits & \multicolumn{2}{|c|}{ No limits } \\
\hline Company stock & Does not satisfy QDIA & $\begin{array}{l}\text { Excluded from } \\
\text { the default } \\
\text { option }\end{array}$ & $\begin{array}{l}\text { May not be part of } \\
\text { LT investment } \\
\text { lineup }\end{array}$ \\
\hline $\begin{array}{l}\text { Discount on } \\
\text { company stock? }\end{array}$ & $\begin{array}{l}\text { Company can offer company stock as an } \\
\text { investment option and can offer a discount } \\
\text { but this is not common }\end{array}$ & Max 20\% & ( \\
\hline Matching & Permitted with maximum rate $100 \%$ & \multicolumn{2}{|c|}{$\begin{array}{l}\text { Permitted with maximum rate of } 300 \% \text {; } \\
\text { match rate may be investment-specific }\end{array}$} \\
\hline Matched funds & $\begin{array}{l}\text { Matching funds sometimes allocated } \\
\text { differently than employee contributions, } \\
\text { can in some cases include company stock }\end{array}$ & \multicolumn{2}{|c|}{ No restriction } \\
\hline $\begin{array}{l}\text { Match formula } \\
\text { and ceiling }\end{array}$ & $\begin{array}{c}\text { Wide variation. Common formulae } \\
\text { include } 50 \% \text { match up to } 6 \% \text { of salary, or } \\
100 \% \text { match up to } 3 \% \text { of salary }\end{array}$ & \multicolumn{2}{|c|}{$\begin{array}{l}\text { Multiple formula allowed, maximum } \\
\text { matching contribution } € 9,414 \text { without } \\
\text { company stock and } € 11,924 \text { with }\end{array}$} \\
\hline Vesting & $\begin{array}{c}\text { Immediate vesting for employee } \\
\text { contributions; employer contributions may } \\
\text { not vest for some period }\end{array}$ & \multicolumn{2}{|c|}{ ( } \\
\hline Early withdrawal & $\begin{array}{l}\text { Permitted for hardship circumstances but } \\
\text { withdrawals taxed as income and } \\
\text { additional } 10 \% \text { penalty tax if withdrawing } \\
\text { before age } 59 \frac{1 / 2}{2} \text { loans against plan assets } \\
\text { also available } \\
\end{array}$ & \multicolumn{2}{|c|}{$\begin{array}{l}\text { Withdrawals under hardship conditions } \\
\text { only, more restrictive for LT than or } \\
\text { MT plans. No penalty for withdrawal. }\end{array}$} \\
\hline
\end{tabular}

